\title{
THE SO-CALLED HADITH QUDSI.
}

Professor Goldziher has shown in his studies of Islam,' that Islam from the earliest century regarded Christianity as a religion from which something could be learned, and did not therefore disdain to borrow from it. This is acknowledged by the Mohammedan theologians themselves. $^{2}$ The early traditions of Islam indeed offer a wealth of examples showing how readily and greedily the founders of Islam borrowed from Christian sources. The miracles recorded in the Gospels were transferred to the realms of Islam, and what Jesus did became the act of Mohammed; for example, the miraculous supply of food or water, and the healing of the sick. Goldziher also enumerates a number of the didactic statements from the Gospels which are incorporated into the Hadith. The most remarkable example he gives is that of the Lord's Prayer: "It is related by Abu Dardai that the Prophet said: "If any one suffers or his brother suffers, he should say: "Our Lord God, which art in Heaven, hallowed be Thy name; Thy kingdom (here apparently the words "come; Thy will be done," are left out) is in heaven and on earth; as Thy mercy is in Heaven, so show Thy mercy on earth; forgive us our debts and our sins (haubana wa khatay'ana). Thou art the Lord of the good; send down mercy from Thy mercy, and healing from Thy healing on this pain, that it may be healed." ",

All these, however, belong to what Moslems call Hadith Nabawi (Traditions of the Prophet) although they are evidently borrowed from other sources. The Hadith Nabarsi are distinguished in Islam from another species of tradition called Hadith Qudsi. This

1 Vol. ii. The Hadith and the Nere Testament.

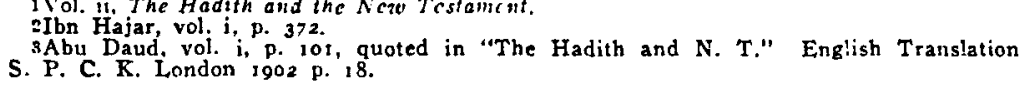


distinction arose from the fact that the former were attributed to Mohammed as the speaker and consisted either of his sayings, his doings or acts which he permitted. These were severally handed down-so it was believedfrom the lips of those who heard the words or were witnesses of the acts in question. But in some cases the form of a tradition showed that it contained the actual word of God, and not the word of the prophet merely. Such traditions were designated as Hadith Qudsi (holy), or Hadith Ilahi (Divine Tradition).

Both kinds of Hadith were held in great reverence from the earliest days of Islam throughout the whole Mohammedan world. The scruples which existed originally against the dissemination and recording of Mohammed's words in writing were soon overcome. The six standard collections of Mohammedan Tradition, so well known, contained not only the sayings of the Prophet and his sunna, i. e. the record of his conduct, but also direct revelations of God to former Prophets, and also to Mohammed himself. Even in the smaller collections of traditions, such as the 'Arabain of $A n-N$ awawi, Hadith Qudsi are found.

The only striking difference is that the Hadith Qudsi at first sight do not seem to have so complete a series of narrators (asnad) attached as do the other traditions. They were doubtless delivered orally by the teacher to the pupil, and there is no record, as far as we can learn, of the date when they were first collected in the form in which they now appear. In fact the whole subject of these Hadith $Q u d s i$ requires further investigation. The Encyclopadia of Islam in the learned article on Hadith by $T$. W. Juynboll gives very meagre information." Hughes' Dictionary of Islam gives nothing. There is scarcely a reference to the subject in the standard Moslem writers on tradition, as far as these have come to our no-

4Eight lines only, ending with the statement that the Leiden MS No. I526, Cat. IV: 88 .
gives a list of them. 
tice. In this outline study we have made use, however, of three standard books. One is the only separately printed collection of Hadith Qudsi namely the "Athafat-asSiniya" by al-Madani (Hyderabad 1323); the second a manuscript by al-Manawi, which we were fortunately able to purchase in Cairo. Brockelmann says (vol. ii, p. 306) that only two copies of this manuscript exist, viz., Leiden No. $176 \mathrm{I}$ and Cairo I. 258.

Finally we consulted a third volume on Hadith $Q u d s i$ of which a manuscript copy is found in the Sultanich Library at Cairo. It is entitled Mi'at Hadith wa Wahid Qudsiy'a by Mohammed Abu Ali ibn Mohammed ibn al-Arabi. He was born $560 \mathrm{~A}$. H. at Mursia, and taught at Seville, afterwards traveling to the Hedjaz, Baghdad and Mosul. He died in Damascus $638 \mathrm{~A}$. H. Al-Arabi is known as one of the greatest mystics in Islam, and was a most voluminous writer. Brockelmann gives a list of his books to the number of one hundred and fifty."

In his introduction Ibn al-Arabi states the origin of his collection of Hadith Qudsi was as follows: "When I came across the saying of Mohammed the Prophet, "Whosoever commits to memory for my people forty Traditions from my lips I will cause him to enter the ranks of those for whom I intercede in the day of Judgment,' and also the statement of the Prophet, 'Whosocver commits to memory for my people forty Traditions that are necessary to them I will record his name as a juriscult and learned man,' in obedience to this statement I have taken pains to collect while at Mecca forty Traditions during the months of the year $599 \mathrm{~A}$. H. and I made it a condition that the first forty of my collection should be directly ascribed to God Himself as the speaker; the second forty through Mohammed as the narrator,--some of which are also narrated by his Companions; and I finally completed the collection, making it up to the number of ror by adding twenty-one Traditions of a similar character. The whole 
collection consists therefore of IOI Divine Traditions (Hadith Ilahi)." This manuscript is dated II 39 A. H.

Our manuscript of Al-Manawi measures six by eight and a half inches, and is on good parchment paper in black ink with red ink headings for each tradition. It consists of sixty-four folios clearly written text in the ordinary Egyptian hand. The one who copied the manuscript calls himself Ibrahim Suwcif as-Shafa'i. The manuscript is dated I $22 \mathrm{~A}$. H. It consists of two parts, the first part, folio I to 38 , contains 273 traditions, each of which begins with the words: "Qal Allah" (God said). The various traditions beginning with this formula are nevertheless arranged alphabetically according to the particular statement that follows. The second part-folio $3^{8}$ to $65-$ consists of ninety-five traditions, some of considerable length, arranged alphabetically, but none of which begin with the usual formula. The printed collection by $\mathrm{Al}$ Madani referred to consists of 239 pages and contains 856 numbered Hadith Qudsi. Of these 164 belong to the first part, each of them beginning "Qal Allah" (God said). Ninety belong to the second part-pages 30 to 46 -and begin with the words "Yaqul Allah" (God says). The third part, from page 46 to the end contains 603 traditions, these are all arranged in alphabetical order.

By comparing the third part with the similar arrangement in al-Manawi it is evident that although some of the traditions in al-Manawi are evidently the same as those in the al-Madani collection, the text is quite uncertain, and. there are many verbal variations. This, however, is not important, as we shall see from the definition given of Hadith Qudsi by Moslems, and the distinction made between these divine sayings and the unchangeable words of Allah as found in the Koran. It is not surprising that the title Hadith Qudsi seemed attractive enough to be used for other collections which are not authentic. One of them is entitled Akhbar Qudsiya, by Abdul Majid Ali, Cairo, $1324 \mathrm{~A}$. $\mathrm{H}$. This book contains no actual sayings 
ascribed to God, but only stories about Mohammed, mostly puerile and of doubtful origin, or evidently recently fabricated. Other similar popular collections exist and have a considerable sale, but they must be carefully distinguished from real Hadith Qudsi. As regards the author of the manuscript collection above mentioned, Abd ar-Ra'af Mohammed bin Taj al-'Arifin Ali bin Zain al-Abadin Zain ad-Din al-Hadadi al-Manawi was of the Shafa'i sect, and was born in Cairo $952 \mathrm{~A}$. H. He busied himself from his youth in theological studies. For a short time he was a Qadi, but soon retired to private life, and studied until he was called to teach in the Madrassa asSakahiya.

His success and reputation awakened enmity and envy, and he died from poisoning after a long and suffering illness, I03I A. H. (I622 A. D.). Nineteen of his writings are catalogued by Brockelmann (vol. ii, p. 306). The most important is called Kunuz al-Haqa'iq fi'l-Hadith, and consists of 10,000 traditions alphabetically arranged, and quoted from no less than forty-four other works on tradition. In addition to his work on the Hadith Qudsi, he wrote a supplement to it on $S u$ fic prayers and traditions called al-Matalib, also many other books, of which a list is found in Brockelmann: they deal with botany, zoology, mineralogy and various other sciences.

For a definition of the term $Q u d s i$ we turn to the appendix of the work by al-Madani. Referring to the dictionary, al-Misbah, he says that the term is derived from the Holy land of Jerusalem, al-Quds quoting also the curious opinion expressed, on the authority of al-Jalabi, that all the traditions called $H$ adith $Q u d s i$ were revealed to Mohammed at the time of his ascent ( $\mathrm{Mi}^{\mathrm{r}} \mathrm{raj}^{\mathrm{j}}$ ) to heaven, and that for this reason they are called $Q u d s i$, because he ascended from a "pure place," namely Bait al. Maqdis (Jerusalem).

This derivation is, however, evidently incorrect; although based on another tradition that Mohammed re- 
ceived all of the Hadith Qudsi at the time of his ascent to heaven from the Holy City of Jerusalem. For in another place al-Madani refers to the dictionary, al-Misbah, and says that the term is applied to the Holy Land of Jerusalem, and that God Himself is called $Q u d u$ s because the word signifies pure or purified.

He then goes on: "As for Traditions being called holy (qudsi), it is because they are related to God as regards the substance and not the form of the narrative. The Noble Koran, on the other hand, came down from God not only in substance but in the very form of its syllables by inspiration to the Prophet Mohammed. Moreover, 'Ali al-Qari, our teacher, said, the Hadith Qudsi is that which the Master of all Narrators and the Full Moon of Authorities (i. e. Mohammed) received from God sometimes by inspiration and again by dream or revelation, leaving him free to express it in words as he pleased. It differs from the Koran in this respect, because the latter only descended from the Preserved Tablet by means of the favour of the Angel Gabriel, accurate in every syllable. Moreover, its transmission was undoubtedly entire, unchanged from age to age. The Koran and the Hadith Qudsi also differ in many other points, among which the learned have enumerated the following:

(1) The Hadith Qudsi may not be used in the repetition of the ritual prayers.

(2) The written Hadith Qudsi is not forbidden to the touch of him or her who is ceremonially unclean. (The text here gives detail in Moslem phraseology.)

(3) The Hadith $Q u d s i$ is not inimitable, in the miraculous sense, as is the Koran. (' $\mathrm{Ijaz}$ )

(4) He who denies the authority or truth of a holy tradition (Hadith $Q u d s i$ ) is not thereby considered an unbeliever (Kafir) as is the case of one who denies the Koran."

Our author then goes on to give his authoritics for these various distinctions, and adds other information. He quotes al-Karmani in his book on Fasting as saying that whatever words have come down to Mohammed without the instrumentality of Gabriel, and without having the 
inimitable form of the Koran, are termed Hadith Qudsi. He says there are also two other terms used: Mlahi (divine) or Rabbani (lordly).

At-Taibi says that the Koran consists of the exact words spoken by Gabriel to the Prophet, while the Hadith Qudsi consists of information of which the significance was given to Mohammed sometimes by revelation and sometimes by dream. This information is quoted from the book alFaw'id by Hafid at-Taftazani.

So much for the significance of the term used. The sources of the Hadith Qudsi, as we shall see from the text later, includes Old and New Testament fragments, of ten torn out of their connection, stray verses from other Apocryphal writers, and (what is most remarkable) abrogated verses of the Koran, which are preserved only in these collections. In some cases a whole Surah apparently, as the Tradition numbered eighty-two in alMadani's printed text." This both in its form and contents is so like the Koran that in reading it aloud to well-read Moslems they affirmed to me it was in the Koran, until shown their mistake.

In this connection we must remember, as remarked by Margoliouth," that "there was no check on the sources of Moslem Tradition. Everything depended on the memory, recollection and of ten the imagination of the narrator. Sometimes the ascription of a saying could be put right. Abu Talib points out that one which was ordinarily ascribed to the Prophet really belonged to the Sufi Saha atTustari of the third century. Some of the Prophet's sayings were referred to earlier revelations, and can indeed be identified in the Bible or Apocrypha. The principle of jurisprudence whereby in civil suits the plaintiff must produce evidence, whereas all that can be demanded of the defendant is an oath, is sometimes referred to Omar,

\footnotetext{
$6 \mathrm{p} .15$. It reads in part as follows: "Then we caused them to inherit the Book, those namily whon we chose from our servants......... and they entered Jaradise without giving account........ verily your Lord is the Forgiver, the Graleful Rewardel, who permitted them to enter the abode of eternity by His graciousness, in which no evil shall
tonch them nor inpure spech harn tlu.m.

Fiarly Devclopment of Mohammedanism, p. 90.
} 
at other times to the Prophet, whereas it really comes from the Jewish Mishna."

This looseness of the whole fabric of tradition is abundantly illustrated by many of the Hadith Qudsi. We can easily understand how these collections of pious sayings were made, and how all sorts of statements which had no authority, save in the fertile brain of those who uttered them, were finally recorded as divine traditions. To quote again from Margoliouth:" "One method of dcaling with the discrepancies between the Biblical narratives and the Koran was to supply the original Bible which the Jews and Christians had been supposed to corrupt. Copies of such works are occasionally found; they are close imitations in style of the Koran, and therefore take the form of addresses by the Divine Being to the Prophets to whom they are supposed to have been revealed. Apparently Sprenger was misled into supposing that a book of this kind bearing the name of Abraham, was the Roll of Abraham to whom some early Surahs of the Koran refer. The Sufi, Abu Talib al-Makki, makes tolerably frequent use of a collection which he calls "The Israelite Traditions," some of which are evidently based on narratives actually found in the Bible. Thus he tells a story of the Temple of Jeroboam, and the adventures of the Prophet who announced its fall, with very fair accuracy: proper names are indeed omitted, and the whole story is a sort of replica of the Mosque of Dirar or "nonconformity," which was built by some of the disaffected near the end of the Prophet's career, and of which the Prophet ordered the destruction; only the prophet who disobeyed the order is shown by a special revelation to have been eaten by the lion not as a punishment, but as an honour. One Khaithamah declared that the Gospel contained a statement about the keys of Korah's treasure-house, which according to the Koran were a load for several persons; the Gospel gave the exact weight." 
Koelle in his "Mohammed and Mohammedanism Critically Considered" devotes the second part of his book to the close parallel between the apocryphal accounts of Mohammed's life in later tradition and the Gospel record of our Saviour Jesus Christ." This is "the mythical Mohammed as he was portrayed by the vivid imagination of his uncritical admirers." "What was known of the lives of previous prophets (or of their sayings) was exaggerated to suit the conception of the chief and seal of all the prophets, such as Mohammed claimed to be, and was most unscrupulously applied to him."11

The system of pious frauds revealed in these collections of Hadith Qudsi is not abhorrent to the Moslem mind. According to their teaching, deception is allowable in such cases. On what occasion would it be more justifiable -not to say meritorious-than in furthering the interests of Islam, and adding glory to the character of Mohammed by supplementing his divine revelation in this way. ${ }^{12}$

We will now let the Hadith $Q u d s i$ speak for themselves. The collection does not merit entire translation, it will $s$ ffice to show from a number of instances the character and sources of some of these Divine sayings, and allow the reader to draw his own conclusions.

The following are examples of some of the more striking Hadith Qudsi translated from al-Madani's collection, chosen because this is the only printed collection of Hadith $Q u d s i$, and its traditions are all carefully numbered. In one or two cases there are repetitions, but I have given some of these in order to show the variations in the text.

"God said: I am in a great difficulty regarding both men and Jinn: I created them, yet they worship others beside $\mathrm{Me}$; I provide them with fond, and then they return thanks to others than Myself." (No. 5.)

"God said: Whasoever has not blessed My judgment, when disaster overtakes him let him seck another Lord than Me." (No.6.)

"God said: If anyone lose his two eycs in My service, I will restore them in Paradise." (No. 14.)

\footnotetext{
10pp. $240-446$.

11 iem, p. 245

12Ci. the remarks of Muir in his Life of Mal mmed vol. 1 , p. LXXIV to LXXIX.
} 
"God said: I have prepared for My servants who are pious, that which eye has not seen, nor ear heard, nor that which has entered into the heart of any man." (This tradition is related on the authority of Bukhari and Muslim, who have it from Abu Hurairi!) (No. 17.)

"God said: My mercy overtakes My wrath." (No. 24.)

"When My servant draw's near to Me a handsbreadth, I draw near to him an armslength; if he draws near to $M e$ an armslength, I draw near to him a fathom; if he approaches Me walking, I approach him running." (No. 28.)

"God said: Pride is My greatness, and majesty My cloak; whosoever deprives $\mathrm{Me}$ of either of them, I will make him taste the torture of the fire." (Repeated I 77.) (No. 34.)

"God said: God loves best those who hasten to worship." (No. 37.)

"God said: If any of $\mathbf{M y}$ servants suffer evil in body, or children, or preperty and bears it with patience, I will reward him on the Day of Judgment by making his account easy." (No. 46.)

"God said: There is no god but God; this is My word and I an He (it). Whosoever, therefore, says this creed enters into $M y$ safekeeping and whosoever enters $M y$ safekeeping is free from My punishment." (No. 49.)

"Gnd said: I am the Lord, and have predestined good and evil; woe, therefore, to him at whose hands I have predestined evil, and blessed is he at whose hands I have predestined good." (No. 50.)

"God said: There are servants of Mine who before inen wear sheep's clothing, but their hearts are more bitter than gall, and their tongues are swceter than honey. They deceive Me." (No. 56.)

"God said: Whenewer My servant thinks of Me I am present in his thoughts; therefore let him think concerning Me as he pleases." (No. 58.)

This tradition repeats $\mathrm{No}_{0} 28$ in other words, both reminding us of the Prodigal's return in Luke, isth Chapter. (No.61.)

"God said: There are three things which if man observe he will be My friend, and if he neglect them My enemy: Prayer, Fanting and Ritual Purification." (No. 74.)

"God said: Whosoever remembers Me in meditation, I will remember him before multitudes of $M_{y}$ angels; whosoever remembers $M e$ in the public assembly, I will remember him before the highest Companionship" (?). (Ar-Rafig al-'Aali.) (No. 77.)

"God said: My servant who believes in $\mathrm{Me}$ is more precious to $\mathrm{Me}$ than some of My angels." (No. 8o.)

(No. 82 is an imitation, both in form and matter, of a Koran Verse, and might be read without distinguishing the difference; one wonders why it was not collected with the other chapters and verses.)

"God said: Whoever is engaged in praying to Me or asking Me a farour, freely 1 will give it to him before he asks." (No. 86.)

"Cod said: Whosoever visits me in Mekka, or at the Mosque of my Apostle in Medina, or at Jerusalem, and dies so doing, will die a martyr." (No. 88.)

"God said: I make a covenant with my servant that if he observes the prayers at the appointed time, I will not punish him, but cause him to enter Paradise without giving account." (No. 93.) 
"God said: My servants cannot array themselves in more proper dress than asceticism." (No. 96.)

(No. 149 seems to be a recollection from the Psalter and reads:"David said: when speaking to God; ' $O$ Lord, which of thy servants is most precious to Thee, so that I may love him with Thy love?' God replied to David: 'The most beloved of My servants to $\mathrm{Me}$ is he who is pure in heart and intent; who does not do evil to anyone, nor walk after back-biting. The mountains may depart, but he who loves Me will abide, and I will love him.' Then David said: 'O Lord, Thou knowest that I love Thee, and love those that love Thee; how shall I show my love to Thee to Thy servants?' He said: 'Remember them in their troubles and in their need, for verily there is no one who assists the oppressed, or walks with him in his affliction, that I will not establish his groodness in the Day when men's footsteps slip.' "

"God said: 'Pride is My cloak and Majesty is My mantle, and whosoever deprives Me of either of them I will cast him into hell." (No. 177.)

(No. 354 is remarkable because according to the authority of as-Suyuti in the Itqan (vol. ii, p. 25, these very words came down to Mohammed as part of the Koran, but were afterwards abrogated. The abrogated verses were preserved in the Hadith Qudsi) "God said: 'Verily we have given men health, that they may perform the prayer and rive alms. If a son of Adam had a parcel of land, he would wish for :Wain: had he twain, he would love to have a third added: nothing will citisfy the desires of man and fill his belly except the dust. After that God will be merciful to him to whom he will show mercy." (No. 354.)

So far the selections from al-Madani.

The following are taken from the collection by alManawi. They differ in no important respect from those by al-Madani, but the following examples are noteworthy.

"Said the Apostle of God: It is written in the Torah, O Son of Man, I have created thee and provided for thee, yet dost thou worship other than Myself." (Folio I, No. 2 of the mss.)

"Those whom I love most among my worshippers are the ones that hasten to break the fast." (Folio 2, No. 6.)

"God said: If any of ny servants purposes to do evil, but does it not, I will consider it to his merit and not to his discredit." (Folio 5, No. I.)

"God said: There are some of those who profess to believe in $\mathrm{Me}$, but in the same breath deny Me. For example, those who say, 'Rain has come down upon us, and we have received our food by the mercy of God, and His bounty.' These are true believers in $\mathrm{Me}$, and do not believe in the influence of the stars. But whosoever says "A certain star has brought us rain or good fortune,' he is an unbeliever.' " (Folio 6, No. r.)

(This gives in almost exact form the text of Isaiah $64: 4$ and 1 Cor. 2:9) "God said: I have prepared for my servants who believe in Me that which eye hath not seen nor ear heard, and that which has not occurred to the heart of man." The asnad or list of narrators for this Hadith is given as follows:- "Ibn Jarir received this from al-Hassan by word of mouth." Other asnad are equally scanty. (Folio 6, No. 3.) 
"God said: The heavens and the earth would not be able to contain Me, yet I dwell in the heart of the true believer." (Folio 6, No. 7.)

"God said to Mohammed: Verily thy people will not cease asking foolish questions, until they say, Behold God has created the creation, but who created God?" (Folio 7, No. 4.)

"God said: I have made a covenant with My servant that if he observes the stated prayers I will not enter into judgment with him, but cause him to enter the Garden without giving account." (Folio 8, No. 7.)

"God said: I am present when My servant thinks of Me, and wheresoever He remembers Me there I am." (This "Tradition is given in various forms on the same page.) (Folio 13, No.6.)

"Said God: The evil eye is a passing-arrow of Satan. Whosoever abandons belief in it because he fears $\mathrm{Me}$, I will give him faith in the place of it, by which he will praise Me in his heart." (Folio 17, No. 5.)

"God said: As you judge you shall be judged, and with the measure by which you mete it it shall be measured to you again." (The complete asnad is given of this Gospel passage, but it is not stated to be from the Injil. Folio 21, No. 2.)

This gives a long tradition in which God says that only their prayers are answered who have fed the hungry, and clothed the naked, and shewn mercy to those in trouble, and visited the stranger. (This is evidently taken from Matthew 25:31.) (Folio 22, No. 7.)

"Whosoever remembers Me rather than begs in prayer, I will give him his request before he asks." (Another form of the scripture statement: "Before they call I will answer.") (Folio 26, No. 6.)

"God said: There is no god but God. This is My' u'ord and $I$ am It. And whosoever pronounces it, I will cause him to enter my safekeeping, and he will suffer no punishment." (Perhaps an echo of John 1: 1 . "In the beginning was the Word and the Word was with God and the Word was God.") (Folio 29, No. 8.)

"God said: O Jesus, I will send after thee a people who when they accept good at $M y$ hands will return praise and thanksgiving, and if they receive that which they dislike, they will still be content and patient." (Evidently a prophecy of the glory of Islam over Christianity.) (Folio 36, No. 2.)

"God said: O Moses, thou son of Amram! Show mercy and you will receive mercy." (This is a gospel beatitude torn out of its connection, and preserved as a Divine word to Moses.) (Folio 37, No. 5.)

"God spoke to Jesus the Son of Mary: Instruct thyself by $\mathrm{My}_{\mathrm{y}}$ wisdom, and if you receive benefit, then teach men; and if not, then fear Me." (Folio 45, No. 3.)

"God revealed to Jesus that He would move about from place to place, so that none could recognize Him and do Him harm. Then God swore by $\mathrm{His}$ greatness and His glory that He would marry Him to two thousand houris, and give Him a vision in Paradise for four hundred years." (Again a caricature of the gospel; many such occur in both collections.) (Folio 45, No. 8.)

The above selections are typical, and although taken somewhat at random represent the contents of the collection fairly well. 
The questions raised in the investigation of this subject are many, both from the standpoint of orthodox Islam and that of the Orientalist and student of Comparative Religion. If these Hadith $Q u d s i$ are Divine traditions and portions of God's revelation to man, why are they not mentioned in the Koran? If they are referred to in the Koran, are they the books that came down to Adam, Seth and other prophets? But these books are supposed to have been lost. How then did these fragments remain? What relation has the Hadith Qudsi to the canonical Gospels or to apocryphal writings? Why did the collectors of Tradition make no distinction between the words of Mohammed, who is, after all, human, and the words which are put into the mouth of God? Why was there never an authentic collection made without variation of the text? What is the relation and the authority of these sayings to the Koran text itself, which is, to the Moslem, the Word of God? What shall we say of the abrogated verse of the Koran, which appears in this collection? Are the other sayings also perhaps portions of the Koran which were abrogated? Or must we conclude, from the standpoint of criticism, that the Hadith Qudsi emphasizes the utterly untrustworthy character of all these collections as regards both the text ( $m a t n$ ) and the narrators (asnad)?

One is reminded of the Hadith preserved by ad-Darimi, and well known (mashhur) to all Moslems: "Inna 'l-hadith qadhin 'ala 'l-Koran wa laisa al-Koran qadhin 'alaihi fi ba'adh al-umur." ("Verily, Tradition determines the significance of the Koran and not the Koran Tradition in certain matters.") One of these matters surely is the conception of inspiration and revelation in the Moslem sense.
Cairo, Egypt.
S. M. ZWEMER. 